\title{
Kitle ve Kültür Turizmi Bağlamında JollyTur ve EtsTur Seyahat Acentelerine Ait İnternet Reklamlarının İçerik Analizi
}

\author{
Zeynep Nihan BAKIR ${ }^{12}$ \\ Hasan Cem ÇELIK ${ }^{3}$
}

\begin{abstract}
Öz
Kapitalizm, dünya genelinde hâkimiyeti ele geçirirken ulusları, sömürenler ve sömürülenler olmak üzere iki ayrı kutba ayırmış ve iş gücünden doğal kaynaklara kadar dünya üzerindeki hemen hemen bütün kaynakları sömürü unsuruna dönüştürmüştür. Bağımlılık Kuramına göre bu sömürü unsurlarının en önemlilerinden bir tanesi, günümüzde turizm sektörü olarak karşımıza çıkmaktadır. Buna göre Batılı merkez ülkeler, az gelişmiş ve gelişmekte olan çevre ülkelere, onların bağımlı konumlarını yeniden üretecek şekilde, kitle turizmini dayatırken, nispeten daha temiz ve prestijli olan kültür turizmini kendi hegemonyaları altında tutmaktadır. Bu çalışmada, Türkiye'de reklam izleyenlere ne tür bir turizmin teşvik edildiğini ortaya koyabilmek amacıyla, JollyTur ve Ets Tur seyahat acentelerinin 2019 senesi boyunca yayınlamış oldukları internet reklamları, niceliksel içerik analizi yöntemi ile çözümlenmiştir. Yapılan çözümlemede, her iki seyahat acentesinin de kitle turizmi temalı reklamlara fazlasıyla yer verdikleri, turizm anlayışını neredeyse tamamı ile deniz-kum-güneş üçlüsü ile sınırladıkları ve kültür turizmini görmezden geldikleri bulgulanmıştır. Çözümleme için belirlenen kategorilerin görüntüsel ve metinsel tekrarları aracılığı ile sözü edilen seyahat acentelerinin, kültür turizmini belli başlı lokasyon ve etkinlik ile sınırladıkları ve reklam izleyenleri kitle turizmine teşvik ettikleri sonucuna varılmıştır.
\end{abstract}

Anahtar Kelimeler: Bağımlıık Kuramı, Kitle Turizmi, Kültür Turizmi, Reklamlar, İçerik Analizi.

Atıf: Bakır, Z. N. ve Celik, H. C. (2020). Kitle ve Kültür Turizmi Bağlamında JollyTur ve EtsTur Seyahat Acentelerine Ait İnternet Reklamlarııı İcerik Analizi. Akdeniz Üniversitesi İletișim Fakültesi Dergisi, 33, s. 318-337

1 Sorumlu yazar (Corresponding author)

2 Doktora Öğrencisi, Akdeniz Üniversitesi Sosyal Bilimler Enstitüsü, zeynepnihan.bakir@hotmail.com, ORCID Numarası: 0000-0001-9989-2042.

3 Dr., Akdeniz Üniversitesi Sosyal Bilimler Enstitüsü, cemcelikrts@gmail.com, ORCID Numarası: 0000-0002-4157-7223. 


\title{
Content Analysis of Internet Advertising of JollyTur and EtsTur Travel Agencies in the Context of Mass and Cultural Tourism
}

\begin{abstract}
While capitalism seized domination around the world, it divided nations into two separate poles, exploiters and exploited, and transformed almost all resources on earth from exploitation to natural resources into exploitation. According to the Dependency Theory, one of the most important elements of this exploitation emerges as the tourism sector today. Accordingly, Western central countries impose mass tourism, under their hegemony, while imposing mass tourism to underdeveloped and developing neighboring countries to reproduce their dependent positions. In this study, in order to reveal that encouraged what kind of advertising monitors tourism in Turkey, JollyTur and EtsTur travel agency of internet advertising which they have issued during the year 2019 were analyzed by quantitative content analysis method. In the analysis made, it was found that both travel agencies place massive advertising on the theme of mass tourism, they limit their understanding of tourism almost entirely to the sea-sand-sun trio and ignore cultural tourism. It is concluded that the travel agencies mentioned through the visual and textual repetitions of the categories determined for analysis restrict cultural tourism to the main location and activity and encourage the audience to mass tourism.
\end{abstract}

Keywords: Addiction Theory, Mass Tourism, Cultural Tourism, Advertisements, Content Analysis.

\section{Giriș}

luslararası sermayenin ilk dönemi, kapitalist toplumlar ile kapitalist olmayan toplumlar arasındaki meta değişimi ilişkileri çerçevesinde gelişmiş ve bu dönem, uluslararası iş bölümü kavramını yaratmıştır (Öztürk, 2006, s. 273). Bu aynı zamanda dünyanın, kapitalist ekonomi sistemi ve sermaye birikimi döngüsüne teslim edildiği anlamına gelmektedir. Yüzyıllar içinde bu sistem genişleyerek dünyanın geride kalan alanlarını da kendi yarattığı işbölümüne dâhil etmiştir (Wallerstein, 2000, s. 4445). Latin Amerika kökenli ve Marksist düşünce temeline dayanan Bağımlılık Kuramına göre, uluslararası sistemde kaynaklar bağımlı ülkelerden temin edilip egemen ülkelere doğru transfer edilmektedir (Erbay ve Özden, 2013, s. 18). Uluslararası ekonomi içerisinde, gelişmekte olan ülkelerin, rekabet şansı bu anlamda azalmakta ve dünya kapitalist sistemi içerisindeki gelişmiş güçler, bu ülkelere kalkınma stratejileri sunarak, kendi faaliyet alanlarını genişletmektedir (Er, 2013, s. 415-421).

Uluslararası iş bölümünde, merkez ülkeler tarafından imalata odaklı fordist dönemde, çevre ülkelerin doğal kaynaklarının talanına, post-fordist dönemde hizmet sektörünün talanı da eşlik etmiştir (Özgüler, 2003, s. 74). Bir diğer ifade ile fordist dönemde, imalat sektörü kitlesel üretim ile birlikte birincil konumdayken, 1960’ı yılların sonuna doğru, üretim biçimi post-fordist sisteme geçerek, üretim süreçleri mekânsal olarak parçalanmış ve imalat sektörünün yerine hizmet sektörü ön plana çıkarılmıştır. (Purkis, 2009). 
Bu anlamda turizm sektörü de hizmet sektörünün en önemlilerinden bir tanesidir ve küresel dünya düzeni içerisinde, merkez-çevre ilişkisi bu sektörde de kendisini hissettirmiştir.

Özellikle 1980'lerden sonra Türkiye'de endüstriyel bir niteliğe bürünen turizm, pek çok üçüncü dünya ülkesinde olduğu gibi giderek kitle turizmi yönünde gelişme göstermiştir. Uluslararası iş bölümünün tüketim kısmını üstlenen Türkiye denizini, güneşini ve kumunu uluslararası tüketim pazarına sunarak dünya turizmine eklemlenmiştir. Uluslararası düzlemde kültür turizmi, yani yüksek gelir getiren, elit ve zengin turistlerin görece temiz turizmi ise birinci dünya ülkelerinin payına düşmüştür (Taşkaya, 2015). Gerçekten de turizm sektöründe çevre ülke konumunda olan Türkiye'de, tarihte birçok uygarlığa ev sahipliği yapış olmasına ve coğrafi ve kültürel açısından son derece zengin bir mirasa sahip olmasına rağmen, kültür turizmine yapılan yatırımların, reklam ve tanıtım hizmetlerinin sayısı son derece azdır. Buna karşııı döviz girdisini ve yabancı turisti kazanmak amacıyla, kitle turizmi ağırlıklı kalkınma politikalarının oluşturulduğu ve kitle iletişim araçları ve sosyal medya kanallarıyla her defasında yeniden üretilen kitle turizminin ön planda tutulduğu görülmektedir.

Bu çalışmada Türkiye'de yaşayan potansiyel turistlere, reklamlar aracılığı ile hangi tür turizmin dayatıldığı ortaya konulmaya çalışıımıştır. Kitle/kültür turizminin reklamlarda sunumuna dair yapılan daha önceki çalışmaların, pazarlama stratejileri ve tüketim pratikleri ekseninde değerlendirildiği görülmüştür. Ne var ki Türkiye'de önde gelen seyahat acentelerinin reklamlarında Türkiye'de yaşayan potansiyel turistlere ne tür bir turizm çeşidini sundukları ve bununla doğrudan ilişkili olarak ne tür bir turizm çeşidini dayattıklarını araştıran herhangi bir çalışma bulunmamaktadır. Bu nedenle, yukarıda sözü edilen amaç doğrultusunda aşağıda yer alan araştırma soruları belirlenmiştir.

- Reklam veren seyahat acenteleri, reklam izleyenlere hangi turizm çeşidini dayatmaktadır?

- Reklam veren seyahat acenteleri, kitle turizmi ve kültür turizmine ne oranda yer vermektedir?

- Reklam veren seyahat acenteleri, reklam izleyenlere kültür turizmini ne ölçüde doğru tanıtmaktadır?

$\mathrm{Bu}$ bağlamda kitle turizminin pazarlama aracı olan JollyTur ve Etstur isimli seyahat acentelerinin, Youtube'da kendi kanallarında bir sene boyunca yayınlamış oldukları reklamlar, içerik analizi tekniği ile incelenmiştir. Bu çalışmaya JollyTur ve Etstur şirketlerinin dâhil edilmesinin temel nedeni, özellikle Türkiye'de resmi tatil öncesi bu seyahat acente reklamlarının diğer seyahat acentelerine kıyasla ulusal televizyon kanallarında ve sosyal medyada daha sık görünür olmasıdır. Bu nedenle, turizm sektöründe öncü konumda ye alan bu iki seyahat acentesinin reklamlarının içerik analizi, Türkiye'deki tatil tüketicilerine hangi tür turizmi dayattığını ortaya çıkarması bakımından önem arz etmektedir. Araştırma sonucunda bu seyahat acentelerinin kültür turizmini görmezden gelerek kitle turizmini teşvik ettikleri, kültür turizmini olması gereken bağlamında tanıtamadıkları ve kültür turizmini Türkiye'de yer alan belli başlı şehir ve lokasyonlar ile sınırladıkları bulgulanmıştır. 


\section{Boș Zaman ve Turizm}

Modern zamanlar ile birlikte çalışan insanların hayatındaki boş zaman olgusunda göz alıcı değişiklikler meydana gelmiştir. Kapitalizmin şaha kalktığı haftada 6 gün ve günlük 16 ile 18 saat arasında değişen çalışma saat ve günleri, bugün çoğu Avrupa ülkesinde haftada 5 gün ve günlük 8 saat ile sınırlandırılmıştır (Haller vd., 2013, s. 404; Castells, 1996, s. 438). Bunun yanında iletişim ve ulaşımda yaşanan teknolojik gelişmeler zamanın hızlanmasına aracılık etmiş; bu da insanların temel ihtiyaçlarını karşılamak adına kendilerine ayırdıkları zaman dilimini artırmıştır (Haller vd., 2013, s. 404). Dünya genelinde yaşanan bu değişimler küreselleşme ile yakından ilişkilidir.

Küreselleşme, dünya üzerinde mal ve hizmetlerin, teknolojinin, emeğin ve sermayenin akışını belirleyen bir kavram olmasının yanı sıra, yenidünya düzeni ilkelerinin benimsenmesini sağlayan, bununla birlikte ekonomik, siyasal, kültürel ve sosyal alanda toplumların üzerinde etkili olduğu, karşılıklı bağımlıı̆ğın giderek arttığı bir süreci ifade etmektedir (Sezgül, 2009, s. 505). Diğer bir deyişle, para ve meta ilişkilerini derinleştiren, yeni yoksulluk alanları yaratan, teknolojinin ve kapitalist işletmelerin belirleyiciliğini pekiştiren, hem yerel hem de dünya ölçeğinde ekolojik ve biyolojik dengeyi bozan, eşitsiz ve asimetrik sonuçları olan bir süreç olarak da ifade edilmektedir (Beaud, 2015, s. 382). Küreselleşme, merkezden çevreye doğru yayılan, merkez ülkelerdeki küresel şirketlerin uluslararası ticaret ile iletişim araçlarını ve bu araçların üretim ve dağıtım kanallarını kontrol ettiği, bunun yanında çevre ülkelerin açık pazar alanı haline gelirken daima kaybeden tarafta yer aldığı sistemdir (Kara, 2014, s. 55).

Küreselleşme sürecini daha iyi anlayabilmek için fordist ve post-fordist üretim biçimlerine kısaca değinmekte fayda vardır. Kapitalizmin sermaye birikim süreci her dönemde sistemin maksimal hedefleri doğrultusunda ilerlerken, değişen üretim biçimleriyle de varlığını devam ettirmiştir. Bu anlamda, fordizm ve post-fordizm olarak adlandırılan üretim biçimleri de kapitalist sistemin devamlılı̆ı için ortaya çıkarılan süreçler olarak düzenlenmiştir.

Fordist sistem, ayrıntılı iş bölümü esasına göre örgütlenmiş makine ile işçi arasında sabit bir ilişkinin kurulduğu hat üzerinde çok sayıda malın ucuza üretilmesi amacını taşıyan, işçi başına üretimin artırıldığı ve işçilerin malın üretim sürecindeki denetimi ve kontrolü en aza indirgenerek, tek amaçı makinalar ve niteliksiz iş gücü kullanılarak üretimin sürekliliğini sağlayan bir sistemdir. Bu sistemin ișleyișini sağlayan üretim alanının oluşması hem standart tüketim kalıplarına hem de geniş pazarların varlığına bağlıdır (Yentürk, 1993, s. 43-44). Kitle üretim sistemi ile üretimin giderek zorlaştığı, hataların telafisinin çok pahalıya mal olduğu bu dönemde, vasıfsız işçiler ile çalışan fordist sistem yeni dünya düzenine kendisini uyarlayamamıştır. Uluslararası rekabeti tetikleyen kriz ortamı Batılı ülkelerin kendi sanayilerini yeniden yapılandırmaya zorlamış ve zaman içerisinde, fordizm yerini post-fordizme bırakmaya başlamıştır (Ansal ve Çetindamar, 2004, s. 176).

Fordist dönemde imalat sektörü hizmet sektörüne göre ön plandayken, üretim de tüketim de kitlesel olarak yapılmaktaydı. Bu üretim biçiminin 1960'ların sonuna doğru kriz yaşamasıyla birlikte, post-fordist dönemde iş gücü piyasaları kutuplaşmış, üretim süreçleri mekânsal olarak parçalanmış ve hizmet sektörü ön planda tutulmuştur. Bununla 
birlikte, gelir düzeyindeki farklılaşmaya paralel olarak tüketim modelleri ve yapısı da değişmiştir (Purkis, 2009, s. 3). Kapitalist üretim sisteminin girdiği krizlerden çıkabilmesi için ortaya çıkan post-fordist üretim sistemi, standart ürünlerden çok çeşitli ürünlere, üretimden emeğin kullanımına, çalışanların iş saatlerine kadar her alanda esneklik getirmiş, toplumsal yaşamda da kapitalist mantığa uyan bir kültürün zeminini hazırlamıştır. Bu kültürel ortamı oluşturmak için, post modernizm de küresel sermaye aracılığı ile işlevlerini yerine getirirken, tüketim kültürünü yaygınlaştırarak azgelişmiş ülkelerde tüketim odaklı yaşam tarzları yaratmıştır (Er, 2014, s. 418-444). Bu yaşam tarzlarının yaratım sürecinde, devletin kontrol ve güç mekanizması yerine, piyasanın kendi ekseni içinde sınırsızlığı ve denetimsizliği yer alırken, dünya pazarı anlayışı içinde bu pazarın kontrolü, çok uluslu şirketler tarafından ele geçirilmiştir. Bu süreçte ise neo-liberalizm siyasi ve ekonomik bir gelişme olarak görülmüştür (Dağtaş ve Dağtaş, 2006, s. 12).

Sonuçta bu dönem, yaratılan her boş zamanın kapitalizme hizmet ettiği, siyasal anlamda kayıtsız, apolitize edilmiş kitlelerin ortaya çıktığı dönemdir. Bu dönem ayrıca medya tarafından sunulan göstergeleri ve imajları tüketen, özellikle kendi özgünlüğünü ve kimliğini yitiren orta sınıfın kendilerini diğer sınıflardan ayırt edebilecekleri ürünlerin üretildiği tüketici topluluğun oluştuğu dönemdir (Dağtaş ve Dağtaş, 2009, s. 70). Üretim biçimlerindeki değişimlere paralel olarak, teknolojinin gelişmesi ve makinelerin yoğun kullanımı insana olan gereksinimi azaltırken, üretim sürecinin mekanikleşmesi ile birlikte iş dışı alan olarak belirlenen boş zamanda da artış gözlenmiştir (Aytaç, 2002, s. 243). Bu anlamda, boş zaman çalışmayı yeniden üretmek ve artan üretimin emilimi için işlevsel bir alan olarak kapitalist sistem için bir arınma ve tüketme zamanı olarak konumlandırımıştır. Dolayısıyla boş zaman, kapitalist sistemi ayakta tutan, ona nefes aldıran bir yapının önemli bir faktörüdür. Kapitalist sistem, emeğin yeniden üretimi için, çalışanların iş dışı yaşam alanlarını tüketim üssü olarak organize etmekte (Aytaç, 2005, s. 6-7), bireylerin çalışma alanlarını ve iş dışındaki boş zamanlarını da tüketim ekseni çerçevesinde, kendi çıkarlarına hizmet etmek için tasarlamaktadır. Kısacası boş zaman, tüketimin sürekliliğini sağlayan, kapitalist sistemin çalışma koşullarını yasallaştıran, çalışanların da tüketici kültürünün içerisinde sistemin devamlılığı için konumlandırıldığı bir araç haline gelmiştir. Bu bağlamda, boş zaman alanı içerisinde yapılan etkinlikler de kapitalist pazarın alanını genişletmektir (Aydoğan, 2000, s. 179).

Çalışmaya hazır bireyler yaratmak adına, iş içindeki yorgunluğun giderilmesine yönelik hizmetler sunan kapitalizm, her alanda olduğu gibi boş zamanı da metalaştırarak piyasa kullanımına sunmaktadır. Bu piyasa alanı da, kârın yükseltilmesi amacıyla toplum ve bireylere suni intiyaçlar ve eğlenceler üreterek, talebin maksimize edilmesi için topluma baskı ve zorlamalarda bulunmaktadır (Aytaç, 2005, s. 6-7). Eğlence ve boş zaman endüstrilerinin bugün dünyada en yüksek kar getiren sektörlerinden bir tanesi de turizmdir.

Uluslararası pazar alanı içerisinde turizm, dünya kapitalist sistemi tarafından kontrol edilen hizmet sektörü içerisindeki büyük bir endüstri konumundadır. Kendi karşıtlığı olarak, düzenli ve örgütlü çalışmayı gerektiren bir olgu olan turizm, bir boş zaman etkinliğidir. Bu anlamda turizm, çalışma ve boş zamanın düzenlendiği toplumsal yaşam alanlarında, ücretli işteki dönüşümlere bağlı olan belirli bir yer ve mekânda organize edilirken, belirli bir zaman aralığında düzenlenerek gerçekleştirilmeye başlamıştır 
(Urry, 2009, s. 16). Endüstri Devriminin akabindeki süreçte çalışma sürelerinin kısalması turizmi geliştiren en önemli etkenlerin başında yer almaktadır. Günlük çalışma saatlerinin düzenlenmesi ve yıllık ücretli izinler ise, insanların boş zamanlarını ortaya çıkararak, yılın belirli aylarını kendilerine ayırıp seyahat etmelerini sağlamıştır (Kozak, 2012, s. 41-42). İş dışı yaşam alanı olarak boş zamanda tatile gidebilme anlayışı, sağlık ve refahla ilişkilendirilerek toplum düşüncesine girmiştir. Bu anlamda "tatile ihtiyacım var" deyişi çalışmanın dışında tutulup zaman tüketimini sağlayan bir gereksinim olarak modern bakışın yansıması konumuna indirgenmiştir (Urry, 2015, s. 195).

Dünya ölçeğinde gelişmiş ve gelişmekte olan ülkeler hizmet sektörünü ve turizmi ön planda tutmuştur. Bu anlamda; dünya turizm endüstrisini kontrol eden çokuluslu şirketler ve onların yapısı içerisindeki ulaşım kanalı olan havayolları, bunun yanı sıra; tur operatörleri ve otel zincirleri de turist akışı denetimini sağlamaktadır. Turizm ürünleri de tüketici istekleri doğrultusunda alternatif ürünler şeklinde (standart/standart olmayan) ortaya çıkarılırken turizm endüstrisi hem fordist hem de post fordist üretim biçimlerini içinde barındırmaktadır (Purkis, 2009, s. 1). Avrupa topluluğu içerisinde yer alan gelişmiş ülkeler, dünya turizm endüstrisi içerisinde mutlak egemen konumunda bulunurken, yoksul ülkeler turizm endüstrisinden orantısız bir şekilde pay almaktadır. Turizm sektörü, Avrupa'da kuzeyden güneye doğru ilerleyen, kaynak akışını yaratan temel bir endüstridir (Urry, 2015, s. 251). Bu anlamda turizm olgusunun gelişimine daha yakından göz atmakta yarar vardır.

\section{Tarihsel Süreç İçerisinde Turizm ve Kitle Turizminin Gelișimi}

Endüstri devriminden sonra, işçi sınıfının ücretli izin hakları kazanması sonucu boş zaman elde etmesiyle kitlesel bir nitelik kazanan ve toplumsal bir olgu haline gelen turizmin geçmişi çok eski tarihlere dayanmaktadır (Tuna ve Yanardağ, 2012, s. 23-45). İnsanlık, tarih boyunca beslenme gereksiniminden dolayı bir yerden diğerine göç ederek, yaşamı için gerekli kaynakları ve verim alınabilecek toprakları bulmak amacıyla sürekli yer değiştirmiştir. Değişim ekonomisinin gerektirdiği ve insan gereksinimlerini karşılamak üzere geçici olarak bulundukları yerden başka bir yere göç edenlere bu dönem içerisinde "tacir" denilmekteydi. İlk çağlara özgü bu yer değişimini ve seyahati gerçekleştiren toplulukların başında ise Finikeliler gelmektedir. İnsanların mekânlar arası yer değişimi toplumsal örgütleşim ile doğru orantılı olduğundan, turizm tarihsel süreç içerisinde toplumsal örgütleşimin varlığıyla birlikte ortaya çıkan bir olgudur denilebilmektedir. Bununla birlikte geçmişteki her uygarlıkta turizm, her dönemde farklı gereksinimlere paralel gelişmiş ve değişmiştir (Eralp, 1983, s. 1). Turizm olgusunun, sınıf farklılıkları temelinde şekillendiği ilk dönem, turizm bilincinin henüz oluşmadığı, daha çok ticaret, din ve sağlık amaçlı kısa mesafeli seyahatlerin gerçekleştirildiği; toplumda üst sınıf mensubu insanların turizm etkinliklerine katılma hakkı ve gücü olduğu bir dönemdir ve "Modern Öncesi Turizm Paradigması"nın hüküm sürdüğü dönemi temsil etmektedir (Kozak vd., 2013, s. 10).

Eski Yunan ve Roma uygarlıkları döneminde, kara ve deniz yolu ulaşım şebekelerinin 
ortaya çıkması ile birlikte seyahat olanaklı hale gelmiştir. Böylece, birbirinden uzak topluluklar arasındaki seyahat süreci de başlamış, sosyo ekonomik alandaki gelişmeler bu dönemde turizm amaçlı gezileri elverişli kılmıştır. Yılın belirli bir döneminin "turizm mevsimi" olarak toplum tarafından genel kabul görmesi ile seyahatin de belirli bir dönemde yapılabilir olması ve bu sebeple işe ara verilmesi, "yıllık tatili" bir boş zaman öğesi olarak sosyal hayata geçirmiştir. Orta çağdaki dinsel hareketler ile birlikte haçlı seferleri ve kıtalararası ticaret ise ülkelerarası seyahati gerekli kılmıştır (Eralp, 1983, s. 4). Orta çağdaki bir başka coğrafyada, Anadolu'da ise, Türk kavimlerinden biri olan Anadolu Selçuklu Beyliği, seyahat edenlere yönelik kervansaraylar inşa etmiş, konaklama ve beslenme gereksinimlerini karşılamak amacı ile ilk tesis anlayışını yaratmıştır (Kozak, 2012, s. 40).

16. yüzyılın başlarında gerçekleşen bilim ve teknoloji alanındaki gelişmeler ve keşifler turizm amaçlı seyahatleri ortaya çıkarmıştır. 17. yüzyıl ise, bilim ile birlikte sanatın ve yeni fikir akımlarının geliştiği döneme işaret ederken, bu dönem içerisinde bilim ve sanat merkezleri de oluşmuştur. Bu merkezlere seyahat edecek olanların, bölge hakkında bilgi gereksinimlerini karşılamak üzere ilk gezi rehberi hazırlanmış, gezi rehberini hazırlayan Fransız piskoposun bu girişimi ise ilk tanıtım ve enformasyon hizmetini simgelemiştir. Bu yapıt ile birlikte günümüzde kullandığımız "tur" sözcüğü turizm diline yerleşmiştir (Eralp, 1983, s. 5-8). 18. yüzyıl ile birlikte, tur kelimesi genç İngilizlerin eğitim amacıyla Avrupa'da bulunan yerleri ziyaret etmelerini ifade etmiş, bu geziler Büyük Avrupa turu ismiyle nitelendirilmiştir (Küçükaslan, 2007, s. 1).

18. yüzyıl aynı zamanda, "Modern Turizm Paradigması"na denk düşen dönemi ifade etmektedir (Kozak vd., 2013, s. 10). Bu dönemde ayrıca Avrupa'nın belli bölgelerinde kaplıca turizmine yönelik kentler, büyük ölçüde bir turist altyapısı oluşturmuştur. Bu yüzyıla kadar olan süreçte, çalışma dışı nedenlerden dolayı "seyahat" bir statü sembolü olarak sadece seçkinler tarafından yapılmış, bu dönemin sonlarına denk gelen demiryolu ulaşımının gelişimi ise, ilk kez kitle seyahatine olanak sağlamıştır (Urry, 2015, s. 194). Ulaşım teknolojilerinin gelişimine paralel olarak kitle seyahatleri ortaya çıkarken, belirli bir sınıfın elde edebildiği tatil ve seyahat kavramı geniş kitlelere yayılmış, bu anlamda aristokrat kesimin tekelinde olan turizm, diğer toplumsal sınıflara doğru genişleyerek sosyal bir gereksinim olarak ortaya çıkmıştır (Kozak vd., 2013, s. 9).

Fransız İhtilali ve Endüstri Devrimi gibi tarihsel gelişmeler, modern turizmin oluşmasına zemin hazırlarken, demiryollarının sivil taşımacılıkta kullanılmasıyla birlikte çok sayıda insanın uzak mesafelere taşınması daha kolay hale gelebilmiştir (Akman, 2007, s. 41). Endüstri Devrimine paralel olarak ilk paket tur ise Thomas Cook tarafından 1841 yılında bu dönemde gerçekleştirilmiş ve turizm ilk kez kitlesel bir görünüme bürünmüştür (Kozak, 2012, s. 41). Bunun yanında 20. yüzyılında meydana gelen iki büyük dünya savaşının ortaya çıkardığı kargaşa ortamı, diğer turizm türlerinin çeşitlenmesini engellemiştir. Ne var ki kitlesel turizm bu dönemde de hızlı bir şekilde yayılmaya devam etmiştir (Karamustafa ve Örnek, 2019, s. 261). Bu kısa tarihçeden de anlaşılacağı üzere, modern turizm ve onun en yaygın türü olan kitle turizmi, geçmişten günümüze bilim ve teknolojideki gelişmeler ve nihayetinde sanayileşmenin yarattığı sonuçlar ile günümüze kadar gelen bir olgu niteliğindedir. Çalışma sürelerinde yapılan değişiklikler, ücretli izinler, insanların boş vakitlerinin çoğalması gibi etkenler ile turizm kitleselleşe- 
rek toplumsal bir olgu haline dönüşmüştür. Diğer yandan kitle turizminin ekonomik ve ekolojik olumsuz etkileri, dünya genelinde alternatif turizm çeşitlerinin de gelişmesine öncülük etmiştir. Bu anlamda son yıllarda özellikle gelişmiş ülkelerde deneyimlenen kültür turizmi de bu turizm çeşitlerinden bir tanesidir.

\section{Kültür Turizmi ve Türkiye’de Turizmin Gelișimi}

Turistlerin deniz-kum-güneş (DKG) tatil turizmi dışındaki, kültürel açıdan zengin yerleri görmek, dünyada kaybolmaya yüz tutmuş yaşam biçimlerini öğrenmek ve bu değerleri bir anı olarak saklama isteği gün geçtikçe artmaktadır (Toskay, 1993, s. 156). Bunun yanında, gelişmiş ülkeler turizmi yılın on iki ayına yayarak, ülke ekonomisine katkısını en üst düzeye çekebilmek adına turizmi çeşitlendirmişlerdir ve bu turizm çeşitlerinin en önde gelenlerinden bir tanesi de kültür turizmidir.

Dünya Turizm Örgütü verilerine göre toplam turizm talebinin \% 37'sini oluşturan ve yıllık \% 15 artış gösteren kültür turizminin (Alaeddinoğlu ve Yıldız, 2007, s. 21) temelinde, kişilerin daha farklı ve otantik yerleri görme isteği yatmaktadır. Kültür turizmi, insanların birbirlerinin yaşam ve düşünce biçimlerini öğrendikleri seyahatin tüm yönlerini kapsar (Goeldner vd., 2000, s. 262). Bununla birlikte, kültür teriminin kapsayıcılığından dolayı, kültür turizminin de birçok farklı tanımı bulunabilmektedir. Ancak yine de 1990'lardan günümüze gelen en özel ve kabul görmüş tanımlardan biri, ICOMOS (Uluslararası Kültür Turizmi Bilimsel Komitesi) tarafından yapılmıştır. Buna göre kültür turizmi, insanların kendileri dışındaki diğer insanların farklı yaşam biçimlerini, geleneklerini, fiziksel çevrelerini, sanatlarını, entelektüel fikirlerini ve daha önceki zamanlardan kalan mimari, tarihi ve arkeolojik kalıntılarını deneyimlemeleri olarak tanımlanabilir (Csapo, 2012, s. 204).

Kültür turizminin kökeni İngiliz elitlerin, çocuklarını eğitim amacıyla Avrupa'nın belirli şehirlerine eğitim amacıyla gönderdikleri "Grand Tour" a dayanmaktadır (Hudman ve Jackson, 1999, s. 26'dan akt. Kozak vd., 2013, s. 13). Ancak Grand Tour sadece İngiliz elitlerin çocukları ile değil, 17. ve 18. yüzyılda özellikle Fransa ve İtalya'da bulunan şehirlere seyahat eden diplomatlar, iş adamları ve akademisyenler ile de can bulmuştur. İlim insanlarının Paris, Roma, Floransa ve diğer kültür merkezlerinde eğitim almasının moda olması sonucu bu tip turlar, basit zevk arayışına tepki olarak, yozlaşmış seyahate karşılık gelişmiştir (Goeldner vd., 2000, s. 52). Ne var ki 18. yüzyıldan itibaren, Dr. William'ın "Deniz Suyunun İyileştirici Etkisi Üzerine Bir Araştırma" adlı çalışması, İngiltere'de insan sağlığını tehdit eden yaşam koşullarının bulunduğu kentlerde yaşayan insanların DKG üçlüsüne akın etmesine, bir diğer ifade ile kitle turizminin muazzam bir şekilde ivme kazanmasına yol açmıştır (Eralp, 1983: 9). Ancak yıllar içerisinde, küreselleşmenin doğal sonucu olarak, insanların intiyaç ve beklentileri çeşitlenmiş ve yenilik arayışları ön plana çıkmaya başlamıştır (Claveria vd., 2015, s. 117). Özellikle 1970'lerden sonra, turizm pazarına hâkim olan kitlesel turizm anlayışı, yerini post-modern bakış açısının yönlendirdiği daha özelleştirilmiş turizm anlayışına bırakmış, bu da turizmin çeşitlenmesine ve kültür turizminin tekrar palazlanmasına olanak sağlamıştır (Roney, 2002, s. 13). Böylece zaman içerisinde, özel sektör ve gönüllü kuruluşların yapmış olduğu tanıtım faaliyetleri, Doğu Avrupa'daki ekonomik ve politik değişimin 
turizmi etkilemesi ve insanların medya aracılığı ile kültür turizmi seçeneğinin farkına varmasıyla, kültür turizmini insanların tercihleri arasında popüler hale getirmiştir (Kızılırmak ve Kurtuldu, 2005, s. 103).

Türkiye de turizm sektörüne, Cumhuriyetin kurulduğu yıllardan 1970'lerin sonuna kültür turizmi ile adım atmasına rağmen, 1980'li yıllardan itibaren gezi-eğlence anlayışına dayalı DKG üçlüsü ülke turizmine ambargo uygulamıştır (Gülcan, 2010, s. 99). Gerçekten de 1990 öncesi Türkiye'nin turizmi incelendiğinde, hayata geçirilen politikaların ödemeler dengesine turizm gelirleriyle pozitif katkı yapmayı, döviz gelirlerini artırmayı, istihdama katkı sağlamayı ve vatandaşlara tatil olanakları sunmayı hedeflediği görülmüştür. Özellikle turizm politikalarında planlı döneme geçildiği 1963 senesinden itibaren, ilk 4 Beş Yıllık Kalkınma Planına bakıldığında, hemen hepsinde kitle turizminin geliştirilmesinin gerekliliği ile ilgili ifadelerin yer aldığı görülmektedir. Turistik tesislerin ve kapasitelerin artırıması, turistik yatırımlara önem verilmesi, turizmin belli yörelerde yoğunlaştırılması, yatırımlara sağlanacak teşvik ve tedbirler, yabancı sermayenin ülkeye çekilmesi, işletmeci ve çalışanlara getirilecek kolaylıklar gibi birçok hedef ve politika, kitle turizmine uygun ve kitle turizminin gelişimine yönelik olmuştur (Gülbahar, 2009, s. 153). İlk kez V. Kalkınma Planı ile birlikte daha öncesinde olduğu gibi kitle turizmine öncelik verileceği, ancak alternatif turizm türlerinin de çeşitlendirileceği ibaresine yer verilmiş ve kültür turizminin de bunlardan bir tanesinin olacağının altı çizilmiştir (Dpt, 1985-1989, s. 120). VI. Kalkınma Planı haricinde, VII ve VIII. kalkınma planları dâhil olmak üzere hiçbir dönemde, kültür turizmi doğru algılanmamış ve bu turizm türüne yönelik politikalar geliştirilememiştir (Alaeddinoğlu ve Yıldız, 2007, s. 23). Diğer taraftan yabancı uzmanların yönlendirmesiyle, Turizm ve Tanıtma Bakanlığı Planlama Genel Müdürlüğü ve Turizm Bankası yetkililerince hazırlanan "Güney Antalya Turizm Gelişim Projesi” 1977 senesinde karara bağlanmıştır (Pekin, 2011, s. 18). 24 Ocak 1980 kararları ve 1982'de yürürlüğe giren 2634 sayılı Turizm Teşvik Kanunu ise Türkiye'deki turizmin gelişmesi açısından milat sayılmaktadır. Alınan kararlar ile birlikte küresel ekonomiye endeksli politikalar uygulamaya konulurken iktisadi, sosyal ve kültürel alanlarda büyük değişimler yaşanmış, üretim ekonomisinden tüketim ekonomisine geçiş hızlanmış ve bir "tüketim toplumu" sürecine girilmiştir (Sezgül, 2009, s. 506). Devalüasyon, yabancı yatırım serbestisi, döviz alış verişi ve yurtdışına çıkışların serbest bırakılması, Turizm Teşvik Kanunu sayesinde turizm sektörüne yatırımların kolaylaşması, vergi-harçlarda indirimlere gidilmesi ve KDV muafiyetleri ile birlikte kitle turizminde büyük bir patlama yaşanmış (Öztaş ve Karabulut, 2006, s. 10-11), "devlet arazisinin tahsisi ile ilgili işlemleri basitleştirmek, yeni turizm türlerinin gelişmesini sağlamak ve tüketici haklarının korunmasında etkili bir kurum olmak" ibaresi ile turizm devlet güvencesine alınmış (Yağcı, 2007, s. 203), 90’lı yıllarda hayata geçen otel ve tatil köylerinde "her şey dâhil sistemi" ile kitle turizmi zirve noktaya ulaşmıştır (Üngüren vd., 2009, s. 101).

Diğer taraftan, ülkedeki küçük çaplı kültür turizmi, kitle turizmi bölgelerine endeksli olarak, kitle turizminin tamamlayıcısı görünümünde gelişme göstermiştir (Alaeddinoğlu ve Yıldız, 2007, s. 24-25). Gerçekten de kültür turizminin en fazla tüketildiği bölgeler arasında yer alan Akdeniz ve Ege bölgeleri dışında kalan iç bölgeler, bu zamana kadar hak ettiği ilgi ve değeri görmemiştir. Bunun yanında DKG üçlüsünün, kültür turizminin 
en fazla tecrübe edildiği bu bölgelere olan ilgiyi yüksek tutan etkenler olduğunu göz ardı edilmemelidir. Her seferinde medeniyetin beşiği olarak tanımlanan Türkiye'de kültür turizminin kitle turizmine kıyasla nerdeyse hiç gelişmemiş olması ise küresel dünya düzeni içerisindeki merkez-çevre ilişkisi ile açıklanabilir. Zira Sharpley'in (2000, s. 5) de belirttiği gibi, turizme eleştirel yaklaşan paradigmalara kaynaklık eden Bağımlıık Kuramı da eleştirilerini merkez-çevre düalizmine dayandırmaktadır.

Sanayi devrimi sonrası, uluslararası iş bölümü, kapitalist sermaye birikiminin ihtiyaçlarına göre şekillendirilmiş ve dünya üzerinde bu eşitsizlik temelli iş bölümünün yayılması ile birlikte, merkez ülkelerde sermaye ve sanayi yer almıştır. Bu merkezlere, hammadde ve tarım ürünleri sağlayan çevre ülkelerden oluşan bir alan yaratılmış, merkez ve çevre ülke ayrımı ile kutuplaşma sağlanmıştır. Kapitalizmin gelişmesi ile birlikte gelişmiş ülkeler (merkez), uluslararası ekonomiyi hâkimiyet altına alırken, çevre ülkeleri azgelişmişlik yapılara dönüştürüp onları edilgen duruma getirmiştir. Bu ülkelerdeki üretim yapıları dış pazarların intiyaçlarını karşılamaya yönelik oluşturulurken, ticaret alanı içerisinde de birbirleriyle alışveriş yapan çevre ülkeler yerine, merkez-çevre ülkeler arasındaki ticaret yapısı oluşturulmuştur (Başkaya, 2005, s. 72-85). Bağımlılık Kuramına göre de az gelişmişlik kavramı dünya kapitalist sistemi ile analiz edilmektedir. Bu bağlamda, İmmanuel Wallerstein ülkeler arası kutuplaşmayı "kapitalist dünya sistemi, merkez-çevre ilişkilerinin hâkim olduğu bir dünya ekonomisi ve devletlerarası bir sistem çerçevesi içindeki egemen devletlerin oluşturduğu bir siyasi yapı tarafından kurulur" şeklinde açıklamaktadır (Wallerstein, 2000, s. 44-45). Dünya üzerindeki eşitsiz dağılım iliş̧ileri çerçevesinde, kapitalist üretim biçimleri de gelişmiş ülkelere hizmet ederek geride kalmış ülkelerin siyasi, iktisadi ve kültürel alanlarını kendi çıkarlarına uygun bir şekilde dönüştürmüş, bu ülkelerin kalkınmasını ve gelişmesini önleyici bir sisteme doğru evrilmiştir.

Küreselleşme ve yenidünya düzenine uyum sağlamanın serbest piyasa ekonomisi temelli bir siyasi ve ekonomik yapılanma ile gerçekleşebileceğini öngören merkez ülkeler, bu doğrultuda çevre ülkelerin ülke politikalarını güçlendirebilecekleri tezini öne sürmektedir. 1970 ve 80'li yıllar ile birlikte Türkiye'de uygulamaya koyulan neo-liberal politikalarla ve bu politikaların uzantısı olarak yukarıda sözü edilen 24 Ocak kararları ve 1982 senesinde yürürlüğe giren Turizm Teşvik Kanunu aracılığı ile yenidünya düzeni ile bütünleşen serbest piyasa sistemi esas alınmış, sosyal devlet anlayışı sınırlandırılıp piyasa devlet ilişkilerinde devletin müdahaleciliği kaldırılarak ekonomik, siyasal ve toplumsal yapının dönüştürülmesi ve piyasa sisteminin tüm alanlarda belirleyiciliği kabul edilmiştir (Sallangül, 2006, s. 302-303). Bu bağlamda, gelişmekte olan ülkeler arasında yer alan Türkiye, gelişmiş ülkelerin talepleri doğrultusunda kamu politikalarını 1960 'ı yıllardan itibaren turizm alanında da yapılandırmış ve kitle turizminin ülkedeki ekonomik etkilerinden faydalanmaya çalışmıştır. Böylelikle yabancı kitle turizmine yönelik teşviklerle, Akdeniz ve Ege kıyılarında yabancı turist sayısında artış meydana gelmiştir. Nitekim kitle turizmi, merkez ülkeler tarafından kontrol edilen, uluslararası sermayenin talepleri doğrultusunda biçimlendirilen ve çevre ülkelerin topraklarında uygulanabilirliği sağlanan bir turizm çeşidi olarak varlığını göstermektedir. Bunun yanında nispeten daha temiz bir turizm olarak adlandırabileceğimiz kültür turizmi ise merkez ülkelerin hegemonyasında tutulmuştur. Ne var ki 1990'lardan bu yana kitle turizminin 
ülkede oluşturduğu olumsuz çevre koşulları büyük ölçüde hissedilmeye başlanmıştır. Bu doğrultuda, dünya üzerinde iktisadi ve çevresel açıdan daha farklı turizm tipleri oluşturulmaya başlanmış ve bu anlamda gelişmiş ülkelerde kültür turizminin sürdürebilirliği sağlanmıştır (Soyak, 2013, s. 1).

Çeşitli ülke deneyimlerinden hareket eden Bağımlılık kuramcıları turizmin olumlu etkilerinin genellikle gelişmiş ülkelerde vücut bulduğunu, yoksul ve az gelişmiş ülkelerde ise genel olarak, batıya yönelik kitle turizmi tarzının hâkimiyetinden kaynaklanan bağımlılık ilişkilerinin olumsuz ekonomik sonuçlara sebep olduğunu vurgulamaktadır (Soyak, 2010, s. 1-5). Özellikle son yıllarda fordist üretim anlayışıyla gerçekleştirilen kitlesel turizm üretimi ve tüketiminin doğal, kültürel ve tarihi kaynaklara zarar vermesi ve turizmin ekonomik getirisinin yılın tamamına yayılması önünde engel teşkil etmesi gibi olumsuz etkileri açısından eleştiriler had safhaya ulaşmıştır (Kozak vd., 2013, s. 18). Gerçekten de kitle turizminin, yoğun turist nüfusunu aynı kısa sezonda genellikle kıyı şeridi üzerindeki konaklatma, yedirme-içirme, eğlendirme, gezdirme ve para harcatmaya dayanan pazar politikası bu alanlar üzerinde taşıma kapasitelerini aşan kullanımları ortaya çıkarmıştır. Bunun yanında tüketim ağırlıklı bu turistik süreç yerel halk ve turist arasındaki ilişkinin kopması, yapılaşma bakımından betonlaşmaya bağlı görsel kirlilik, ekolojik çevrede yoğunluk, kaynak kullanımı bakımından çevresel kirlilik, kirliliğe bağlı tür kayıpları ve ekolojik dengenin bozulması, sosyo-kültürel farkılıılar ve beklentilerin uyuşmaması bakımından kültürel bozulma ve çok uluslu tur operatörlerine bağımlılık olarak kendini göstermiştir (Ovalı, 2007, s. 64; Uçkun ve Türkay, 2003). Ancak tüm bu eleştirilere rağmen bazı ülkelerin "ne pahasına olursa olsun ekonomik büyüme" mantığı ile turizme yaklaştığı görülmektedir (Kozak vd., 2013, s. 18). Batıya yönelik kitle turizmi tarzını benimseyen bu ülkelerin seyahat acenteleri, özellikle paket tur-her şey dâhil sistemler ile bağımlıığı en üst düzeye taşıdıkları gerekçesiyle Bağımılık kuramcıları tarafından şiddetle eleştirilmektedir (Soyak, 2016).

\section{Yöntem}

Bu çalışmada, Türkiye'deki ulusal televizyon kanallarında en çok reklamları görünen ve turizm sektöründe adından sıkça söz edilen JollyTur ve Etstur seyahat acentelerinin, video paylaşım sitesi Youtube'da kendi kanallarında yayınlanan reklamları incelenmiştir. Adı geçen seyahat acentelerinin, reklamları izleyenlere ne tür bir turizm çeşidini dayattıklarını ortaya koyabilmek için niceliksel içerik analizi tekniğinden yararlanıımıştır.

Herhangi bir yazılı, görsel ya da işitsel iletide bulunan bağlamlar, anlamlar, alt metinler ve niyetler üzerine yapılan çalışma olan içerik analizi söylenen, yazılan veya kaydedilenlerin "objektif" analizidir. Bu bağlamda Stone ve arkadaşları (1966, s. 5) içerik analizini, metin içindeki belirli karakteristikleri sistematik ve nesnel olarak tanımlayarak çıkarımlar yapmak için kullanılan bir çözümleme tekniği olarak tanımlamaktadır. İlk zamanlar araştırmacılar, içerik analizini yalnızca nicel ya da yalnızca nitel bir yöntem olarak kullansalar da (Berelson, 1952), bu analiz tekniği ilerleyen yıllarda nicel olarak kodlanan istatistiki verilerin nitel olarak yorumlanmasına evrilmiştir (Morgan, 1993). Bu çalışmada analiz birimi olarak belli bir sıklıkla tekrar eden görüntü, konuşma, yazılı metin, kelime, terim, tema ve karakterlerin tamamı esas alınmıştır. Böylece, görün- 
tülerin ve metinlerin temaları ortaya çıkarılmış; görüntü/metinlerde kullanılan ve belli bir sıklıkta tekrar edilen anahtar kelimelerden oluşan bir indeks belirlenmiş; görüntü/ metin içeriğinde yer alan turizm çeşitlerine yönelik kullanılan betimleyici özellikler tespit edilmiştir. Bu amaçla incelenen her internet reklamı, görüntüsel ve metinsel olarak iki ayrı kodlama çizelgesine belirlenen temalar doğrultusunda kodlanmıştır. Görüntüsel kodlama yapılırken, belirlenen görseller internet reklamının başlaması ile sayılmaya başlanmış ve sayma işlemi reklam sonunda reklam şirketinin logosunun görünmesi ile sonlandırılmıştır. Belirlenen temalar her sahnede ayrı ayrı sayılmıştır. Söz gelimi bir sahnede kumsalda yürüyen bir aile görüntülenmiş ise "aile" ve "kumsal" ayrı ayrı birer kez kodlanmış; takip eden sahnede farklı bir aile aynı kumsalda yürümüş ise "aile" ve "kumsal" yine ayrı ayrı birer kez daha kodlanmıştır. Böylelikle sözü edilen seyahat acentelerinin, belirlenen görüntülere kitle turizmi ve kültür turizmi bağlamında ne kadar ve ne süre ile yer verdikleri tespit edilebilmiştir.

Metinsel kodlamada ise reklam boyunca ekranda beliren yazılar ve reklamda geçen diyaloglar kodlanmıştır. Örneğin bir sahnede ekranda "eğlence" kelimesi görünmüş ve takip eden farklı bir sahnede "eğlence" kelimesi bir kere daha görünmüş ise "eğlence" kelimesi iki kez kodlanmıştır. Bu şekilde yapılan bir çözümleme ile sözü edilen seyahat acentelerinin, reklam izleyicilerini ne tür bir tatile teşvik ettikleri ve bahsi geçen turizm çeşitlerini ne şekilde tanımlandıkları anlaşılabilmiştir.

Bu bağlamda, kitle turizmini betimleyen görsel ve metinler alfabetik sırayla aile-sevgili, aktivite-eğlence, arkadaşlar, deniz, deniz-kum-güneş, doğa, gün batımı, güneş, hamam-sauna, havuz, kumsal ve yeme-içme olarak belirlenmiştir. Bununla birlikte parti, dans, kayak, yüzme, su sporları, grup sporları ve otellerde akşam gerçekleştirilen eğlenceye dayalı her türlü etkinlik "aktivite-eğlence" temasına dâhil edilmiştir. Kültür turizmini betimleyen görsel ve metinlerde ise alfabetik sıraya göre antik kentler, deniz, deniz-kum-güneş, doğa, ibadethane, köprü, mezar, mimari, tiyatro, Kapadokya, Kayaköy, Side, Sümela Manastırı ve Türkiye'nin beli başlı şehirleri kodlanmıştır.

\section{Evren ve Örneklem}

Bu çalışmanın evrenini, 2019 yılı içerisinde bütün seyahat acentelerinin, video paylaŞım sitesi Youtube'da kendi kanallarında yayınladıkları turizm reklamları oluşturmaktadır. Amaçlı örneklem çerçevesinde, ulusal televizyon kanallarında periyodik olarak en çok reklamları gösterilen Jollytur ve Etstur şirketleri çalışmanın örneklemini oluşturmaktadır. Anıtur, Gezinomi, Tatil, Tatilbudur, TatilSepeti, Touristica, Setur gibi seyahat acentelerin çoğu, kendi Youtube kanallarında 2019 senesi içerisinde reklam videosu yayınlamamıştır. Reklam yayınlayan acentelerin ise bu reklamları sınırlı sayıda tutmasından dolayı, adı geçen bu acenteler örnekleme dâhil edilmemiştir.

\section{Sinırlılıklar}

Bu çalışma, video paylaşım sitesi Youtube'da 01.01.2019 ile 31.12.2019 tarihleri arasında yayınlanan reklamlar ile sınırlıdır. Bunun yanında 2 dakikayı aşan, farklı tarih- 
lerde birden fazla tekrarlanan aynı reklamlar ve ne kitle ne de kültür turizmi olarak tanımlanamayan reklamlar çözümlemeye dâhil edilmemiştir.

\section{Araștırmanın Bulguları}

Araştırmanın bu bölümünde, JollyTur ve Etstur şirketlerinin kendi Youtube kanallarında 2019 senesi boyunca yayınlamış oldukları reklamlar, görüntüsel ve metinsel veriler üzerinden analiz edilmiştir.

\subsection{JollyTur ve Etstur'un Youtube'da Yayınladıkları Reklam SayıSı}

Tablo-1: 01.01.2019 ve 31.12.2019 Tarihleri Arasında Youtube'da Yayınlanan Reklam sayısı

\begin{tabular}{lcccc}
$\begin{array}{l}\text { Seyahat } \\
\text { Acentesi }\end{array}$ & $\begin{array}{c}\text { Kitle Reklamı } \\
\text { (Adet) }\end{array}$ & $\begin{array}{c}\text { Kitle Reklamı } \\
\text { (Saniye) }\end{array}$ & $\begin{array}{c}\text { Kültür Reklamı } \\
\text { (Adet) }\end{array}$ & $\begin{array}{c}\text { Kültür Reklamı } \\
\text { (Saniye) }\end{array}$ \\
\hline JollyTur & 42 & 1.568 & 26 & 656 \\
Etstur & 136 & 6.455 & 18 & 870 \\
Toplam & $\mathbf{1 7 8}$ & $\mathbf{8 . 0 2 3}$ & 44 & $\mathbf{1 . 5 2 6}$
\end{tabular}

Tablo 1'den de anlaşılacağı üzere, JollyTur ve Etstur seyahat acenteleri 2019 senesi içerisinde toplamda 222 adet reklam yayınlamıştır ve bu reklamların toplam süresi 9.549 saniye, yani yaklaşık 160 dakikadır. Yayınlanan bu 222 reklamın 178'ini kitle turizmi reklamları oluştururken geri kalan 44 reklamı kültür turizmi reklamları oluşturmaktadır. Bir diğer ifade ile yayınlanan toplam reklamların \% 80'i kitle turizmi reklamlarıdır. Seyahat acentelerinin bu turizm çeşitlerine ayırmış oldukları süreler de reklam sayılarındaki görüntü ile benzerlik göstermiştir. Toplam 9.549 saniyelik görüntünün \% 84'ü kitle turizmine aittir. Şirketler ayrı ayrı incelendiğinde de JollyTur'un \% 70, Etstur'un \% 84 oranında kitle turizmine yönelik görüntü verdiği tespit edilmiştir. Bu verilerden hareketle, her iki seyahat acentesinin de kültür turizmine kıyasla kitle turizmine ağırlık verdikleri, bunun doğal sonucu olarak da bu seyahat acentelerinin, reklam izleyenlere kitle turizmini dayattıkları rahatlıkla söylenebilir. Zira belli bir temaya, diğer temalara kıyasla daha fazla yer vermek, o temaya verilen önemin açık bir göstergesidir.

Tablo-2: Kitle Turizmi Reklamlarında Kullanılan Görüntüler ve Sıklıkları

\begin{tabular}{|l|c|l|c|l|c|l|c|}
\hline \multicolumn{3}{|c|}{ JollyTur Kitle Turizmi Görüntüleri } & \multicolumn{4}{c|}{ Etstur Kitle Turizmi Görüntüleri } \\
\hline Aile-Sevgili & 28 & Gün Batımı & 13 & Aile-Sevgili & 118 & Gün Batımı & 12 \\
\hline Aktivite-Eğlence & 179 & Güneş & 10 & Aktivite-Eğlence & 532 & Güneş & 57 \\
\hline Arkadaşlar & 13 & Hamam-Sauna & 10 & Arkadaşlar & 19 & Hamam-Sauna & 57 \\
\hline Deniz & 64 & Havuz & 79 & Deniz & 140 & Havuz & 310 \\
\hline Deniz-Kum-Güneş & 192 & Kumsal & 3 & Deniz-Kum-Güneş & 368 & Kumsal & 17 \\
\hline Doğa & 21 & Yeme-içme & 14 & Doğa & 112 & Yeme-içme & 227 \\
\hline
\end{tabular}


Reklam endüstrisi bir yandan dâhil olduğu tüketim ideolojisi çerçevesinde kendini saydamlaştırmaya ve ekonomik çıkarlar doğrultusunda kültürel, toplumsal ve politik tavırları desteklemeye aracılık ederken, diğer yandan sunmuş olduğu ürünü dayatma veya inkâr etme işlevini de başarıyla yerine getirerek tüketim ideolojisinin taşıyıcılığını da yapmaktadır (Tuncer, 2010, s. 88). Bu açıdan bakıldığında, JollyTur ve Etstur reklam filmleri, kitle turizmi endüstrisini destekleyerek geleneksel kitle turizmi anlayışının devamlılığını sağlayan bir figür olarak karşımıza çıkmaktadır. Gerçekten de tablo 2 incelendiğinde, her iki turizm firmasının reklam filmlerinde görüntüleri belirli temalar üzerinde yoğunlaştırdıkları görülmektedir. Her iki seyahat acentesi de görüntülerde en fazla "DKG" ve "aktivite-eğlence" temasına yer vermiş, bu temaları "deniz", "havuz" ve "doğa" temaları takip etmiştir. Özetle kitle turizminin itici gücü olan bu temalar ile tatil anlayışı DKG ve eğlenceye indirgenmiştir. Bunun yanında "aile-sevgili" temasının da reklam filmlerinde sıkça kullanılması, kitle turizminin topluca yapılan bir tüketim turizmi olduğunu göstermesi açısından son derece önemlidir.

Tablo-3: JollyTur Kitle Turizmi Reklamlarında Kullanılan Metinler ve Sıklıkları

\begin{tabular}{|l|c|l|c|}
\hline \multicolumn{4}{|c|}{ Tekrarlanan Metinler ve Sıklıkları } \\
\hline Aile & 14 & Lüks & 2 \\
\hline Aktivite-Eğlence & 39 & Parti & 5 \\
\hline Rüya Gibi & 12 & Keyif & 9 \\
\hline Doğa-Manzara & 3 & Konfor & 5 \\
\hline Deniz & 17 & Kumsal & 4 \\
\hline Eşsiz & 8 & Mimari & 1 \\
\hline Güneş & 11 & Tarih & 1 \\
\hline Havuz & 9 & Yemek & 7 \\
\hline
\end{tabular}

Çözümlemesi yapılan seyahat acentelerinden Etstur, reklamlarında herhangi bir yazılı ya da sözlü metin kullanmadığı için, bu bölümde sadece JollyTur'un reklamlarında yer alan metinlerine yer verilmiştir. JollyTur'un kitle turizmi reklamlarında kullanmış olduğu yazılı ve sözlü metinleri gösteren tablo 3'ten de anlaşılacağı üzere, reklam izleyenler "keyif", "aktivite-eğlence" vaatleri ile cezbedilmiş, vaatler "rüya gibi, unutulmaz, eşsiz, harika, lüks, konfor" kelimeleriyle pekiştirilmiş, "aile" ile turizmin toplu tüketimi teşvik edilmiştir. Kültür turizminin göstergeleri olan "tarih" ve "mimari" metinleri ise kitle turizmi kapsamındaki 42 reklam içerisinde sadece birer kez tekrar edilmiştir.

Tablo-4: JollyTur Kültür Turizmi Reklamlarında Kullanılan Görüntüler ve Sıklıları

\begin{tabular}{|l|c|l|c|}
\hline \multicolumn{4}{|c|}{ Tekrarlanan Görüntüler ve Sıklıkları } \\
\hline Antik Kent & 39 & Mezar & 16 \\
\hline Cirit & 1 & Mimari & 33 \\
\hline Deniz & 18 & Tiyatro & 11 \\
\hline Deniz-Kum-Güneş & 21 & Kapadokya & 10 \\
\hline Doğa & 73 & Kayaköy & 11 \\
\hline
\end{tabular}




\begin{tabular}{|l|c|l|c|}
\hline Ibadethane & 2 & Side & 10 \\
\hline Kale & 1 & Sümela Manastırı & 10 \\
\hline Köprü & 12 & Yöresel Yemek & 6 \\
\hline
\end{tabular}

Kültür turizmi reklamlarında kullanılan görüntüler incelendiğinde orman, kanyon, vadi, dere ve akarsudan oluşan "doğa"nın en sık kullanılan tema olduğu görülmektedir. Doğadan sonra en sık tekrarlanan temalar ise sırası ile "antik kent" ve "mimari"dir. Antik kent ve mimari temasının çok sık tekrarlanması, kültür turizmi reklamları özelinde beklenen bir durumdur. Ancak tabloda esas dikkat çekici olan "DKG" ve "deniz" temalarının, kültür turizminin uğrak yeri olabilecek diğer temalardan çok daha fazla tekrarlanmış olmasıdır. Bu durum Türkiye açısından değerlendirildiğinde, kitle turizminin temel dayanağı olan DKG üçlüsünün, kültür turizmi için de can alıcı öneme sahip olduğu ve kültür turizminin tamamlayıcısı olduğu anlaşılmaktadır. Ancak unutmamak gerekir ki kitle turizmi ve kültür turizmi birbirlerinin alternatifleri değildir. Bir diğer ifade ile sözü edilen seyahat acentesi açısından kültür turizmi kavramı, yukarıda daha önce ICOM'un yaptığı ve genel kabul görmüş tanımla örtüşmemektedir. Zira "kültür turizmi" tanımının göndermede bulunduğu ata sporları, tarihi kaleler, ibadethaneler ve yöresel yemekler gibi temalar neredeyse hiç gösterilmemiştir. Bunların dışında kalan tiyatro, Kapadokya, Kayaköy, Side ve Sümela Manastırı onar kez tekrar edilmiştir. Bu sayı ilk bakışta çok gibi gözükse de aslında bu temalar birer kez gösterilmiştir. "Antalya çıkışlı kültür turları" başlığı ile açılan bir reklam filmi, diğer dokuz reklam filminde aynı görüntüler üzerinde sadece şehrin ismi değiştirilerek verilmiş; başlıklar her seferinde değiştiği için diğer dokuz reklam da ayrı bir reklam olarak değerlendirilmiştir. Böylece aslında bir kez gösterilen bu temalar toplamda on ayrı reklamda gösterildiği için toplam sayıyı yükseltmiştir. Etstur adına herhangi bir tablo düzenlenmemiştir; zira yayınlamış olduğu toplam 870 saniyeden oluşan 18 reklam filminin tamamı, Kapadokya'yı tanıtmaktadır. Özetle kültür turizmi kavramı, adı geçen seyahat acenteleri açısından olması gerektiği anlamda içselleştirilememiş ve reklam izleyenlere anlatılamamıştır. Bu durum reklamlarda kullanılan metinlerde de kendisini göstermektedir.

Tablo-5: JollyTur Kültür Turizmi Reklamlarında Kullanılan Metinler ve Sıklıkları

\begin{tabular}{|l|c|l|c|}
\hline \multicolumn{4}{|c|}{ Tekrarlanan Metinler ve Sıklıkları } \\
\hline Adana & 1 & İzmir & 1 \\
\hline Ankara & 1 & Kayaköy & 2 \\
\hline Antalya & 1 & Keşif & 10 \\
\hline Artvin & 3 & Mardin & 1 \\
\hline Bursa & 1 & Memleket & 1 \\
\hline Bu Topraklar & 3 & Mezar & 3 \\
\hline Erzincan & 1 & Trabzon & 1 \\
\hline Gaziantep & 1 & Türkiye & 1 \\
\hline Hatay & 3 & Samsun & 1 \\
\hline Şanlıurfa & 5 & & \\
\hline
\end{tabular}


Turist üreten pazarlara bağımlı olan destinasyonların ziyaretçiler tarafından tercih edilmesinde, seyahat acentelerinin tavsiye ve yönlendirmeleri etkili olmaktadır (Atay ve Yıldırım, 2009: 119). Bunun yanında reklam filmlerinde kullanılan dil de seyahat acentelerinin izleyicileri ne tür bir turizm çeşidine yönlendirdiklerini anlamamız açısından bize ipucu vermektedir. Etstur yayınlamış olduğu hiçbir reklamda, herhangi bir yazılı ya da sözlü metin kullanmadığı için tablo 5'te sadece JollyTur'un kullanmış olduğu metinlere yer verilmiştir. Blumler'e (1986, s. 172'den akt. Yaylagül, 2019, s. 331) göre medya bir yandan gündem yaratarak izler kitlenin ne hakkında düşüneceğini belirlerken, diğer yandan da seçilen kelime ve kavramlarla nasıl düşüneceklerini belirler. Diğer bir ifade ile reklamlarda kullanılan metinler, izleyicilerin düşüncelerini biçimlendirir ve çerçeveler. Bu bağlamda JollyTur, kullanmış olduğu metinlerde Türkiye'deki 81 ilin sadece 13'üne yer vermiş ve kültür turizmini bu illerin sınırları içine hapsetmiştir. Yani 10 defa ile en fazla tekrarlanan kelime olan "keşif" bu 13 ilin sınırları içerisinde kalmıştır. Bu 13 ilden en fazla tekrarlanan yer ise son yıllarda popülaritesi artan Göbeklitepe'nin kendisine getirdiği avantaj sayesinde Şanlıurfa olmuştur. "Bu topraklar" 3 kez "Türkiye" ve "memleket" ise 26 reklamda sadece birer kez tekrar edilmiştir.

\section{Sonuç ve Tartıșma}

Bu çalışmada JollyTur ve Etstur seyahat acentelerinin, video paylaşım sitesi Youtube'da kendi kanallarında 2019 senesi boyunca yayınlamış oldukları reklamlar içerik analizi tekniği ile incelenmiş ve adı geçen seyahat acentelerinin, reklam izleyenleri ne tür bir turizme yönlendirdikleri sorusuna cevap aranmıştır. Elde edilen bulgulara göre, her iki seyahat acentesinin de kitle turizmi içerikli reklamlara adet ve süre olarak ağırlık verdikleri, kültür turizmi içerikli reklamların ise yok denecek kadar az olduğu görülmüştür. İki seyahat acentesinin de her beş reklamın dördünde kitle turizmine yönelik reklam yayınlaması, bunun yanında süre olarak her bir dakikanın yaklaşık kırk sekiz saniyesini kitle turizmine ayırmış olması ise bu seyahat acentelerinin, reklam izleyenleri kitle turizmine yönlendirdiklerinin açık bir göstergesi olarak yorumlanmıştır. Zira daha önce de belirtildiği gibi, belli bir temaya diğer temalara kıyasla daha fazla yer vermek, o temaya verilen önemin kanıtı niteliğindedir.

İncelenen her iki seyahat acentesi de kitle turizmi reklamlarında kullanılabilecek birçok tema içerisinden en fazla DKG üçlüsü ile aktivite/eğlence temasını kullanarak turizm anlayışını bu iki tema üzerinden görselleştirmiş ve tatil anlayışı ve algısı bu iki temaya indirgemiştir. Bu duruma ek olarak JollyTur, kullanmış olduğu sesli ve yazılı görseller ile bu temaları pekiştirmiş, keyif, konfor, muhteşem, rüya gibi, harika gibi kelimeler kullanarak, reklam izleyenlerin bilinçaltına seslenmiştir.

Kültür turizmi reklamlarında en sık kullanılan temalar antik kent ve mimari olsa da DKG üçlüsünün bu reklam çeşidinde de çok kullanıldığı görülmüş ve bu durum kitle turizminin bel kemiği olan DKG üçlüsünün, kültür turizmi için de itici güç olduğu şeklinde yorumlanmıştır. Ancak bu durumun tam tersi olarak, kültür turizminin tanımlayıcısı olabilecek temalara neredeyse hiçbir kitle turizmi reklamında yer verilmemiştir. Bunun yanında, her iki seyahat acentesi de kültür turizmini tema ve lokasyon açısından doğru tanımlayıp değerlendirememiştir. Tarih öncesi devirlerin en önemli örnekleri Türkiye 
topraklarında olmasına rağmen, JollyTur kültür turizmini Türkiye'deki 81 ilin 13'ü ile Etstur ise sadece Kapadokya sınırlamıştır.

Uluslararası turizm eksenindeki ülkeler, turist ve döviz girdisinin yanında, uluslararası sermaye tarafından yönetilen seyahat acenteleri ile birlikte teknoloji, finansman ve tüketim merkezli batı kültürüne de topraklarını açmaktadır. Bu bağlamda, az gelişmiş ülkelerin yenidünya düzeniyle bütünlük sağlamaları batı tarafından desteklenmekte ve kitle kültürü az gelişmiş ve gelişmekte olan ülkelere empoze edilmektedir (Roney, 2002, s. 12). Sonuç olarak adı geçen seyahat acenteleri, kültür turizmini görmezden gelerek, reklam izleyenleri kitle turizmine yönlendirmektedir. Türkiye'de tarihsel ve kültürel mirası, kültür politikalarını dikkate almayan, bunları vizyon ve misyonunun odak noktasına oturtmayan bir turizm anlayışı uzun vadede başarısız olmaya mahkumdur. Böylesi bir turizm anlayışı, ardında sadece geri dönüşü ve telafisi olmayan doğal, ekonomik, toplumsal ve kültürel bir enkaz bırakır (Pekin, 2011, s. 14). Hâlbuki binlerce yıldan beri birçok medeniyete ev sahipliği yapmış olan Türkiye, kültür turizmi açısından dünyanın en uygun bölgelerinden biridir ve bu konuda söz sahibi olabilmek adına öncelikle tarihi, kültürel varlıkların ve geleneklerin değerini Türkiye'de yaşayan insanlar bilmelidir (Gülbahar, 2009, s. 173). Bu anlamda Çatalhöyük, Alacahöyük, Troya, Çayönü, Efes, Anadolu Selçuklu Beylikleri ve Osmanlıdan günümüze gelen eserler, dünyanın yedi harikasından ikisi olan Artemis Tapınağı ve Halikarnas Mozolesi, başta kutsal emanetler olmak üzere, İslami öğeler, külliyeler, saraylar, camiler, Tevrat peygamberlerinin izleri, Yahudi sinagogları, Hristiyanlık için çok önemli olan Yedi Kilise, ilk kilise ve daha binlercesi ile adeta bir açık hava müzesi olan Türkiye'nin (Pekin, 2011, s. 28-30), tarihsel envanteri çıkartılarak seyahat acenteleri, sivil toplum kuruluşları ve Kültür ve Turizm Bakanlığı'nın iş birliği ile Türkiye, Türkiye'de yaşayan insanlara layıkıyla tanıtıımalı ve bu konudaki milli şuur, daha ilköğretim çağından itibaren yaratılmaııdır. Bunun yanında tarihi eserler orijinaline sadık kalınarak restore edilmeli, müzecilik geliştirilmeli ve bu alanda eğitimli kişiler sektöre kazandırılmalıdır (Gülbahar, 2009, s. 174). Son olarak, kültür turizminin uzun vadeli faydalarını en üst düzeye çıkarmak için, yeri doldurulamaz kültür ve miras kaynaklarının korunmasını ve uygun kullanımını sağlayacak etkili yönetim stratejileri geliştirilmesine dikkat edilmelidir. Bu anlamda telafisi mümkün olmayan hasarların daha da derinleşmemesi adına, kitle turizmi kültür turizminin uzantısı olarak yeniden düzenlenmelidir.

\section{Kaynakça}

Akman, D. (2007). Turizm Gelişmesinin Yarattığı Doğal Ve Kültürel Değişimler: Kaş Örneği. (Yayınlanmış Yüksek Lisans Tezi). Ankara: Ankara Üniversitesi Sosyal Bilimler Enstitüsü.

Alaeddinoğlu, F. ve Yıldız, M.Z. (10-15 Eylül 2007). "Türkiye'de Kültür Turizmi ve Algılanışı, Kültürel Değişim, Gelişim ve Hareketlilik”, 38. Uluslararası Asya ve Kuzey Afrika Çalışmaları, Ankara.

Ansal H. ve Çetindamar, D. Teknolojik Gelişmelerin Ölçek Ekonomisine Etkileri, Kapitalist Üretim Esneklik Kazanıyor: Post-Fordizm. Iktisat Dergisi, 30 (346).

Atay, L. ve Yıldırım, M. (2009). “Türkiye'de Seyahat Acenteciliğinin Gelişimi” Türk Turizm Tarihi. 
Ş. Çavuş, Z. Ege, O. Eralp (drl.) Detay Yayıncılık, Ankara

Aydoğan, F. (2000). Medya ve Serbest Zaman. İstanbul: Om Yayın Evi.

Aytaç, Ö. (2002). Boş Zaman Üzerine Kuramsal Yaklaşımlar. Fırat Üniversitesi Sosyal Bilimler Dergisi, 12(1), 231-260.

Aytaç, Ö. (2005). Kapitalizm ve Boş Zaman. 14 Kasım 2016 tarihinde (http://dergipark.ulakbim. gov.tr/ogusbd/article/view/5000080813/5000074926) adresinden edinilmiştir.

Başkaya, F. (2005). Azgelişmişliğin Sürekliliği. Ankara: Maki Basın Yayın.

Beaud, M. (2015). Kapitalizmin Tarihi .(F. Başkaya, Çev.), İstanbul: Yordam Kitap.

Berelson, B. (1952). Content Analysis in Communication Research. Glencoe IL, Free Press.

Claveria, O., Monte, E., and Torra, S. (2015). Common Trends İ İnternational Tourism Demand: Are They Useful To Improve Tourism Predictions?. Tourism Management Perspectives, (16), 116-122.

Csapo, J. (2012). The Role and Importance of Cultural Tourism in Modern Tourism Industry, Strategies For Tourism Industry- Micro and Macro Perspectives. M. Kasımoğlu ve H. Aydın (drl.). Croita: Vana Persen.

Dağtaş,E ve Dağtaş,B. (2006). Tüketim Kültürü, Yaşam Tarzları, Boş Zamanlar ve Medya Üzerine Bir Literatür Taraması. Eğitim Bilim Toplum Dergisi, 4(14), 4-31.

Dağtaş, B. ve Dağtaş, E. (2009). Medya, Tüketim Kültürü ve Yaşam Tarzları. Ankara: Ütopya Yayınları.

DPT, Beşinci Beş Yıllık Kalkınma Planı 1985-1989

Er, K. (2014). Üretim İlişkileri Temelinde Modernizm ve Post Modernizmin Azgelişmiş Ülkeler Üzerine Etkileri”. Dokuz Eylül Üniversitesi Sosyal Bilimler Enstitüsü Dergisi, 3(16), 413-453.

Eralp, Z. (1983). Genel Turizm. Ankara: Ankara Üniversitesi Basın Yayın Yüksekokulu.

Erbay, E.R. ve Özden, M. (2013). İktisadi Kalkınma Kuramlarına Eleştirel Yaklaşım. Namık Kemal Üniversitesi Sosyal Bilimler Metinleri, 3.

Goeldner, R.C., Ritchie, B. and Mcintosh, R. (2000). Tourism: Principles, Practises, Philosophies, 8th Editioni. John Wiley

Gülbahar, O. (2009). 1990’lardan Günümüze Türkiye'de Kitle Turizminin Gelişimi ve Alternatif Yönelimler. Süleyman Demirel Üniversitesi Iktisadi ve İdari Bilimler Fakültesi Dergisi, 14(1)

Gülcan, B. (2010). Türkiye'de Kültür Turizminin Ürün Yapısı ve Somut Kültür Varlıklarına Dayalı Ürün Farklılaştırma İhtiyacı. İşletme Araştırmaları Dergisi, 2(1)

Haller, M., Hadler, M., and Kaup, G. (2013). Leisure Time in Modern Societies: A New Source Of Boredom and Stress? International Journal Of Methodology, 111(2), 403-434.

Kara, T. (2014). Kültür Endüstrisi Kavramı Çerçevesinde Medya Ürünleri: Eleştirel Yaklaşım. The Turkish Online Journal of Design, Art and Communication, 4(1)

Karamustafa, K. ve Örnek, N. (2019). Modernite ve Postmodernite Etrafında Şekillenen Turizm 
Kızılırmak, İ. ve Kurtuldu, H. (2005). Kültürel Turizmin Önemi ve Tüketici Tercihlerinin Belirlenmesine Yönelik Bir Çalışma. Gazi Üniversitesi Ticaret ve Turizm Eğitim Fakültesi Dergisi, (1), 100-120.

Kozak, N. (2012). Genel Turizm Bilgisi. Eskişehir: T.C. Anadolu Üniversitesi Yayını.

Kozak, M., Evren, S. ve Çakır, O. (2013). "Tarihsel Süreç İçinde Turizm Paradigması". Anatolia Turizm Araştırmaları Dergisi, 24(1), 7-22.

Küçükaslan, N. (2007). Özel İlgi Turizmi. Bursa: Ekin Yayınevi.

Morgan, D. L. (1993). Qualitative Content Analysis: Aguide to Paths Not Taken. Qualitative Health Research. 02 Ocak 2020 tarihinde https://www.researchgate.net/publication/14741101 adresinden edinilmiştir.

Ovalı, P. (2007). Kitle Turizmi ve Ekolojik Turizmin Kavram, Mimari ve Çevresel Etkiler Bakımından Karşılaştııııması. Yıldız Teknik Üniversitesi Mimarlık Fakültesi E-Dergisi (2), 64-79.

Özgüler, V. (2003). Yeni Ekonomi Anlayışı Kapsamında Gelişmiş ve Gelişmekte Olan Ülkeler: Türkiye Örneği. T.C Anadolu Üniversitesi Yayınları; No:1479 Iktisadi ve İdari Bilimler Fakültesi Yayınları (179)

Öztaş, K. ve Karabulut, T. (2006). Turizm Ekonomisi: Genel Turizm Bilgileri. Ankara: Nobel Yayın.

Öztürk, Ö. (2006). "Emperyalizm Kuramları ve Sermayenin Uluslararasılaşması", Praksis, (271309).

Pekin, F. (2011). Çözüm: Kültür Turizmi. İstanbul: Illetişim Yayınları.

Purkis, S. (17-19 Haziran 2009). Dünya Turizm Endüstrisinin Örgütlenmesi ve Marmaris Örneği. Econ Anadolu2009: Anadolu International Conference in Economics. Eskişehir, 1-15.

Roney, S. (2002). Fordizmden Post Fordizme Geçiş Sürecinin Turizme Yansımaları: Kitle Turizmi ve Alternatif Turizm, Anatolia: Turizm Araştırmaları Dergisi, 13(1), 9-14.

Sharpley, R. (2000). Tourism and Sustainable Development: Exploring the Theoretical Divide. Journal of Sustainable Tourism, 8(1), 1-19.

Sallangül, S. (2006). Sosyal Devlet Bitti Yaşasın Piyasa Yeni Liberalizm ve Muhafazakârlık Kıskacında Refah Devleti. Ankara: Ebabil Yayıncılık.

Sezgül, İ. (2009). "Küreselleşme, Neo-Liberalizm ve Etik”. Tübav Bilim Dergisi, 2(4), 504-509.

Soyak, A. (2010). Turizm Sektöründe Bağımlıı̆ın Sonuçları ve Politika Önerileri. 22 Aralık 2016 tarihinde http://alkansoyak-yazilari.blogspot.com.tr/2011/04/turizm-sektorunde-bagmllgnsonuclar-ve_24.html. adresinden edinilmiştir.

Soyak, M. (2013). Uluslararası Turizmde Son Eğilimler ve Türkiye'de Turizm Politikalarının Evrimi. Marmara Sosyal Araştırmalar Dergisi, (4)

Soyak, M. (2016). Türk Turizm Sektörünün Yapısal Analizi ve SWOT Matrisine Dayalı Sektörel Stratejiler. 1. Marmara Sosyal Araştırmalar Dergisi, (10): 47-71. 
Stone, P.J., Dunphy, D.C., Smith, M.S., and Ogilvie D.M. (1966). The General Inquirer: A Computer Aproach to Content Anaylsis. MIT Press, Cambridge.

Taşkaya, M. (2015). Somut Olmayan Kültürel Mirasın Aktarımında Ekonomik ve Politik Arkaplan: Toplumsal Hafıza, Aidiyet, Kimlik, İdeoloji, Medya ve Turizm Endüstrisi. 24 Aralık 2016 tarihinde http://akademikstok.com/somut-olmayan-kulturel-mirasin-aktariminda-ekonomik-vepolitik-arka-plan-toplumsal-hafiza-aidiyet-kimlik-ideoloji-medya-ve-turizm-endustrisi-oku-323. $\mathrm{html}$ adresinden edinilmiştir.

Toskay, T. (1993). Turizm. İstanbul: Der Yayınları.

Tuna, M ve Yanardağ, A. (2012). Turizm Sosyolojisi. Eskişehir: Açıköğretim Fakültesi Yayını.

Tuncer, E. (2010). Televizyon Reklamlarında Geleneksel Anne Imgesi: Bingo Örneği.

(Yayınlanmış Yüksek Lisans Tezi). İstanbul: Maltepe Üniversitesi Sosyal Bilimler Enstitüsü.

Uçkun, G ve Türkay, O. (2003). Alternatif Turizm Sürdürülebilirliği. Ankara Üniversitesi Çankırı Meslek Yüksek Okulu Konferans Bildirileri

Urry, J. (2009). Turist Bakışı. (E. Tataroğlu ve İ. Yıldız, Çev.), Ankara: Bilgesu Yayıncılık.

Urry, J. (2015). Mekânları Tüketmek. (R. G. Öğdül, Çev.), İstanbul: Ayrıntı Yayınları.

Uygur, M. ve Baykan, E. (2007). Kültür turizmi ve turizmin kültürel varlıklar üzerindeki etkileri. Gazi Üniversitesi Ticaret ve Turizm Eğitim Fakültesi Dergisi, (2), 30-49.

Üngüren, E., Algür, S. ve Doğan, H. (2009). Konaklama ve Seyahat Acenteleri Yöneticilerinin Her Şey Dâhil Sistemine Yönelik Tutumları: Antalya örneği. Karamanoğlu Mehmet Bey Üniversitesi i.i.B.F. Dergisi, Aralık: 95-112.

Yağcı, Ö. (2007). Turizm Ekonomisi. Ankara: Detay Yayıncılık.

Yaylagül, L. (2019). 31 Mart 2019 Mahalli İdareler Seçiminin Sabah ve Sözcü Gazetelerindeki Sunumunun Karşılaştırmalı Olarak İncelenmesi. Akdeniz Iletişim Dergisi, (32), 323-339.

Yentürk, N. (1993). Post-Fordist Gelişmeler ve Dünya İktisadi İş Bölümünün Geleceği. Toplum ve Bilim Dergisi, Bahar: 56-61.

Wallerstein, I. (2000). Bildiğimiz Dünyanın Sonu. (T. Birkan, Çev.), İstanbul: Metis Yayınları. 